\title{
El camaleón que se sustenta del aire: evolución paremiológica e incidencia en la literatura española
}

\author{
The Chameleon that Feeds On Air: \\ Paremiological Evolution and Incidence in Spanish Literature
}

\author{
Rafael MALPARTIDA \\ (Universidad de Málaga) \\ rmal@uma.es \\ ORCID ID: 0000-0001-8438-9014
}

\begin{abstract}
The current speaker immediately associates chameleons with color change, but seems confused with the idea that this animal feeds on air, when it emerges in a literary text. Speakers do not recognize as their own, therefore, the proverb Sustentarse del aire como el camaleón, which has been transmitted along several centuries in collections of proverbs and has been frequently used for its stylistic value and its effectiveness as a comparison in literature. This paper tries to explain the doggedness of the idea (even after the error has been realized) and its evolution as a proverb, showing the communicating vessels between the cultured and popular traditions. It ultimately advocates for the recovery and the examination of what could be considered a «pre-truth», since it exemplifies what Nuccio Ordine called, in his defense of the Humanities, «the usefulness of the useless».
\end{abstract}

KEYWORDS: chameleon; paremiology; symbology; Pliny the Elder; Belon; Terreros; Correas; Sbarbi.
RESUMEN. El hablante actual asocia al camaleón inmediatamente con el cambio de color, pero le causa desconcierto la noción de que el animal se alimente del aire cuando aflora en un texto literario. No reconoce como suya, en consecuencia, la paremia Sustentarse del aire como el camaleón, que ha perdurado durante varias centurias en las colecciones paremiológicas y se ha empleado con frecuencia por su valor estilístico y su eficacia como símil en la literatura. A explicar esa persistencia en la idea (incluso una vez sabido el error) y su evolución como paremia, mostrando los vasos comunicantes de la tradición culta y de la popular, se encomienda este artículo, que en última instancia aboga por la recuperación y estudio de lo que podríamos considerar una «preverdad» porque ejemplifica lo que Nuccio Ordine llamó, en su defensa de las Humanidades, «la utilidad de lo inútil».

PALABRAS-CLAVE: camaleón; paremiología; simbología; Plinio el Viejo; Belon; Terreros; Correas; Sbarbi.

\section{ENCAUZAMIENTO: PERCEPCIÓN ACTUAL SOBRE EL CAMALEÓN}

Todo estudio sobre paremiología, en especial si aborda aspectos genealógicos o evolutivos, debería efectuar un trabajo de campo, o partir al menos de alguna observación que determine el vigor del elemento analizado. El saber popular (o lo que hemos convenido en llamar así, asociado a la paremia) y sus manifestaciones particulares mantienen su latido, vivificándolo, o bien lo atenúan, y hay que comprobar su vigencia. 
Eso resolvería, de paso, la tensión (cuando no paradoja) entre oralidad y escritura que subyace al estudio paremiológico y sus plasmaciones literarias.

En el caso que nos ocupa, no serán necesarios gráficos sofisticados para desvelar estadísticas. Se trata de una experiencia docente repetida, a modo de juego, durante más de una década, con alumnado de entre 18 y 30 años (al principio de Grado, pero sobre todo, durante los últimos cursos, de Posgrado, con lo cual habríamos de precisar entre 23 y 30 años de media). El texto de partida que les he propuesto para que reflexionen sobre la labor filológica (y su componente axial de curiosidad) es el siguiente:

Leandro: Dios te dé buena ventura, que más nos hartará tu buena voluntad y gracia que todos los manjares y vinos del mundo; y pues que así es, comencemos a comer, que en verdad yo estaba medio desmayado con pensar que esta noche la habíamos de pasar como camaleones (Torquemada, 2011: 161).

Ante ese fragmento dialogal, del que solo he mudado aquí una de las intervenciones, y en particular ante la referencia al camaleón (que no les pasa nunca desapercibida), las intuiciones del alumnado van siempre en la dirección de una propiedad muy determinada del reptil: su cambio de color ${ }^{1}$. Esta respuesta (previsible, desde luego) es un festín para el filólogo y, cómo no, para que ellos, como filólogos en formación, reflexionen sobre su propia disciplina; de ahí mi persistencia con ese texto durante tantos años.

El fragmento, que remite indudablemente a la alimentación, igual que los turnos de diálogo que lo rodean («alguna cosa que comamos», «cecina», «liebre», «agua», «banquete», «apetito», «hambre» y un largo etcétera), no activa en ellos el resorte de una característica que durante muchas centurias (sobre todo desde Plinio, como veremos, hasta bien entrado el siglo XVIII) ha cobrado forma (más perifrástica) de paremia y (más concentrada) de símil, y ha nutrido de manera extraordinaria la literatura: que el camaleón se alimenta solo del aire.

No debo poner objeción alguna a la aparente contradicción de que un texto que gira en torno a la comida no resemantice al camaleón en esa línea, sino que convoque una cualidad conocida y tenida por cierta por parte del alumnado: la del cambio de color. La no alimentación o alimentación del aire resulta tan increíble para un hablante actual, que solo la erudición (y en este caso a partir de un error) podría salvarla para el entendimiento cabal del texto, que a la sazón pulsa un menosprecio de corte y una alabanza de aldea gracias a esas referencias. Y es que esa erudición a que apelamos (a menudo, justo es decirlo, con pretenciosidad) los docentes está conformada no por verdades, sino por pulsiones del conocimiento (de ahí el término amplitud con que el DLE la define en su segunda acepción) que no tienen por qué haberse mantenido estables. Reconocer esos vaivenes e indagar en sus causas forma parte de la investigación filológica, porque un error tan notable como ese forma parte, asimismo, de la literatura. Así de sencillo: no hay que desestimar nada, por muy disparatado que se juzgue. El filólogo, en suma, tiene algo de síndrome de Diógenes: todo lo guarda, por inservible que pudiera parecer.

${ }^{1} \mathrm{Y}$ con dificultad para determinar si de la idea se desprende, desde un punto de vista metafórico, una cualidad positiva o negativa. Téngase en cuenta que esas reservas responden en realidad a dos tendencias bien refrendadas por los estudiosos, como en la asociación de esta característica del animal, en contexto áulico, con la figura de Proteo, hasta el punto de que se produjo toda una «controversia sobre el significado ético de la imagen del camaleón en el mundo de la corte» (Álvarez-Ossorio, 2000: 112). De su ambivalencia simbólica (y en variadas tradiciones) informan también oportunamente Chevalier y Gheerbrant (1986: 239240). 
Muy llamativo resulta, además, que una vez iluminada la oscura referencia (con manifiesta sorpresa para el alumnado), siempre empleen la expresión de que nunca lo habían «oído». Aquí no se trata, significativamente, de «leído». Contamos con numerosas compilaciones, con o sin glosa, de refranes y proverbios, pero persiste la idea de «oído». Nótese que intuitivamente el alumnado alude a fuentes de transmisión oral: no lo reconocen porque no lo han heredado. En cambio, la otra propiedad, la del cambio de color, sí les resulta familiar justamente porque lo camaleónico (concepto que termina emergiendo) sí les «suena». Todos estos términos que emplea el alumnado nos ponen, claro, en la órbita de la oralidad, y refrendan lo que Juan de Mal Lara denominaba «filosofía vulgar» porque el refrán (o, como prefiero aquí de forma más neutra, paremia) «se conservó con el repetirlo y dezir comúnmente», y así discurre «natural y estampado en memorias y en ingenios humanos» (1996: 31), o, si se quiere una explicación más moderna, lo que sintetiza así Vicente González Martín:

El pueblo toma, guarda y aplica un proverbio como si fuera fruto de su cosecha lingüística y no de la literaria o del ingenio de alguien, observador e ingenioso, que, oralmente o por escrito, nos las han legado para su aplicación, uso y servicio de todos, hasta llegar a formar parte de la conciencia lingüística colectiva y anónima de un determinado pueblo (1997: 286).

La paremia responde a una necesidad comunicativa, y une lo colectivo con lo particular. Crea un nexo, una vinculación consensuada. Para designar al que padece mucha hambre, como el Leandro de nuestro texto, el hablante de hoy no necesita al camaleón porque no piensa en él para ese aspecto. No lo asocia porque no cree que el camaleón no se alimente. Es más, relaciona al animal con dos peculiaridades, el cambio de color y - precisamente- su modo de alimentarse, con esa enorme y llamativa lengua que, claro, ya ha tenido oportunidad de contemplar, probablemente a través de imágenes, tanto fijas como en movimiento. Esta iconosfera en que nos movemos cortocircuita (por vía contraria: no solo come, sino que lo hace de modo muy notable) un arraigado topos.

Por otra parte, lo que seguramente desconcierta al alumnado es la expresión tan elíptica o condensada (en forma de símil como los recogidos en el siglo XVI por Pérez de Moya o los lugares comunes de Aranda), frente a la forma consignada por Martínez Kleiser, ya expandida y con marcas más reconocibles de proverbialidad: Del aire se mantienen los camaleones, pero no los hombres (1993: 27). Ante esa formulación ya tendrían claro, al menos, que de nutrición estamos tratando, aunque les quedaría por desentrañar por qué se dice que el camaleón se mantiene del aire.

Hay, por tanto, tres razones de muy diferente tenor para que la expresión desoriente al hablante actual y no la reconozca como parte de su patrimonio: en primer lugar, desde un punto de vista científico, la protesta por algo que resulta inconcebible; en segundo lugar, desde un prisma comunicativo, la ausencia de transmisión oral de algo que se percibe perteneciente a esa esfera y no a la escrita; y, por último, desde predios estrictamente linguiísticos, la formulación condensada y elíptica, que da por entendido lo que precisamente no entiende el receptor moderno.

Sentadas estas premisas, es necesario preguntarse de dónde procede la idea, generadora de la paremia, de que el camaleón no se alimenta, y cómo se ha ido cimentando con la inestimable ayuda de la literatura, que constituye lo que podríamos denominar «la memoria del error». 


\section{ASOCIACIÓN DEL CAMALEÓN CON EL AIRE Y VAIVENES DE UN ERROR}

Martínez Kleiser consigna el citado refrán dentro del apartado dedicado al alimento (1993: 27-28), donde menudean ejemplos muy dispares, y de ahí procede la principal objeción que se ha hecho a tan magna obra: la imprecisión taxonómica (Sevilla Muñoz, 1996: 651). No obstante, la vinculación del camaleón con el aire no es solo semántica, como podría parecer en este caso, sino que contiene resonancias míticas. En una franja mucho más próxima al bestiario ( $\mathrm{y}$, por qué no decirlo ya decididamente, en particular al fantástico), el reptil comparte mención habitualmente con otros animales que se sustentan solo de un elemento, conformándose así un selecto club de cuatro (con alguna variante, pero ofrezco la «reunión» más aceptada): el camaleón, del aire; la salamandra, del fuego; el topo, de la tierra; el arenque, del agua. No es de extrañar que tengamos que indagar en este componente mítico porque «su naturaleza es tremendamente prodigiosa», como se dice en un bestiario medieval (Malaxecheverría, 1986: 114) del camaleón y podríamos decir nosotros mismos tantos siglos después. Como explica John Berger en su precioso texto «¿Por qué miramos a los animales?», «en todas partes, los animales ofrecían explicaciones o, más exactamente, prestaban su nombre y su carácter a una cualidad, la cual, como todas las cualidades, era, en esencia, misteriosa» (2008: 14). Asociado al aire figura el reptil en la emblemática y la iconología, cuya complejidad y riqueza en su tratamiento daría para un artículo monográfico. Me contento con citar a Alciato, que insiste, «contra los aduladores», en que «Está el camaleón la boca abierta / y de ayre se mantiene» (2003: 118), y a Cesare Ripa, que describe al Aire como una

mujer con los cabellos levantados y esparcidos al viento [...]. Volando se han de ver diversos y numerosos pájaros, mientras a los pies de la figura se ha de poner un camaleón, animal que ni bebe ni come cosa alguna, sino que sólo vive y se alimenta del aire, según lo dice Plinio (1987: 305).

De ahí que, por vía iconográfica y simbólica, «los artistas eligiesen al camaleón como atributo del elemento AIRE personificado» (Mariño Ferro, 1996: 81). Pero lo que más interesa para el recorrido que vamos a trazar, es que tanto la versión mítica como la científica no solo han convivido armónicamente, sino que han coincidido en sus estimaciones. Baste citar a un compilador como Juan de Aranda para refrendar: «Dizen los naturales que ay animales que se sustentan de los quatro elementos, como el topo de la tierra, los peces del agua, el camaleón del ayre y la salamandra del fuego» (1613: $\left.196 v^{\circ}\right)$. Es decir, que una mente «supersticiosa» y una «racional» (la de esos «naturales», a los que hoy llamaríamos «naturalistas» o estudiosos de las ciencias naturales, como el Plinio al que ya remitía Ripa) comparten percepción. Esto, que resulta muy sorprendente para el hablante actual que considera ajena a su mundo esta propiedad del camaleón, es simplemente la confluencia, tantas veces atestiguada, de dos ramas del saber fuertemente imbricadas, y que discurren parejas a dos ámbitos, el de la oralidad y el de la escritura, que tampoco han resultado ser, naturalmente, compartimentos estancos (antes al contrario: de su afluencia continua se ha nutrido el conocimiento).

Atiéndase, por tanto, a que ese extraño sustento del aire lo aceptan y difunden, en buena medida, «los naturales». Plinio el Viejo, el pionero «natural» por excelencia (y a su zaga Solino, aunque con mucha menor incidencia) ${ }^{2}$, indicó del camaleón lo siguiente:

\footnotetext{
${ }^{2}$ En sus valiosas notas al pasaje de Solino (que calca a Plinio), el responsable de la edición, Francisco J. Fernández Nieto, llama la atención sobre Juba de Mauritania (además de Aristóteles, como es bien sabido) como fuente para el capítulo de la Historia Natural sobre el camaleón (Solino, 2001: 498). No obstante, en
} 
«Anda siempre levantado, la boca abierta, y solo entre todos los animales no come manjar alguno; antes sin comer y sin beber se sustenta solamente del aire» (Huerta, 1602: 249).

Cito por la traducción castellana de Jerónimo de Huerta porque su glosa es preciosa para nuestro cometido: «Belonio dice que sufre la hambre ocho meses y un año, y que se sustenta de moscas y de mosquitos y de otros insectos, los que les ase con la lengua, que es para este fin muy suelta, pegajosa y larga» (1602: 249).

Veamos, pues, lo que señala Pierre Belon (Bellonius latinizado, Belonio castellanizado) en particular, porque ya hay claros indicios por parte del comentarista, al contrastar información, de que Plinio se equivocó al transmitir la idea: al naturalista francés no le cabe duda, en efecto, de que «il se nourrit de mousches, chenilles, escharbots et sauterelles, vivant à la maniere des serpents, qui mangent toutes sortes de petites bestes insectes, lesquelles l'ay souvent trouvé regardant en son estomach quand l'en faisoye l'anatomie» (1554: 98). No obstante, matiza de inmediato, sabedor de lo arraigado del tópico, que «aucuns ont dit que les cameleons vivent seulement de vent», a lo que da una explicación muy convincente por similitud con la serpiente:

Or est il qu'un cameleon demeurera un an en vie sans rien manger, qui n'est pas chose difficile à croire, car j'ay veu des serpents de diverses sortes vivre l'espace de dix mois sans leur donner aucune chose à manger. Vray est qu'il faut leur bailler quelques fois un peu d'eau à boir (1554: 98-99).

Belon apela ya a su experiencia (en este caso, acerca de las serpientes) y apunta a que el no haber visto comer al camaleón no se debe a que no lo haga, sino a que puede pasar mucho tiempo sin hacerlo ${ }^{3}$. Plinio, en cambio, usó principalmente fuentes librescas, pese a la imagen que difundió su sobrino, Plinio el Joven, muy potente y hermosa, pero apologética (e incluso heroica), de que murió en la erupción del Vesubio en el año 79 porque, «como hombre sabio que era, le pareció que se trataba de un fenómeno importante y que merecía ser contemplado desde más cerca» $(2005: 307)^{4}$. Como al camaleón (más manso que el volcán) no pareció haberlo observado por sí mismo, parece necesario recordar, con Benjamin Farrington, que

Plinio no aporta nada original a la ciencia excepto su omnívora curiosidad por todos los secretos de la naturaleza, curiosidad que considera que únicamente él poseía entre los

lo relativo a la alimentación del aire, ni Aristóteles (1992: 104-106) ni Juba II (al menos en los textos recuperados y traducidos por García García, 2007) aportan dato alguno.

${ }^{3}$ El argumento se repetirá, por ejemplo, a propósito de una mención elíptica de Ovidio («Id quoque, quod uentis animal nutritur et aura, / protinus adsimulat, tetigit quoscumque, colores», 1990: 183) en las anotaciones a las Metamorfosis de Sánchez de Viana (1589: 304v-305). Torquemada lo achaca, por otra parte, en su Jardín de flores curiosas a una cierta «adaptación natural» (lo cual implica, claro, aceptar el tópico): «a todas las cosas les es propio y natural aquello en que se crían: y así como un hombre que de pequeño se comenzó a poner en costumbre de comer poco a poco algunas cosas ponzoñosas, después aunque las coma en una gran cantidad no le hacen daño, lo cual se ha visto ya por experiencia, de la mesma manera, un hombre criado en el frío, cuanto más va creciendo, menos perjuicio y daño le hace. Y así lo tienen por su natural: como el pescado tiene andar en el agua, y la salamandra criarse y vivir en el fuego y el camaleón sustentarse con el aire» (1982: 428).

${ }^{4}$ De ahí que señalara además, respecto a la Historia Natural de su tío, que «los hombres son curiosos por naturaleza, y se dejan seducir, por simple que sea el relato de los hechos, de tal modo que son atraídos con los comentarios y las anécdotas más irrelevantes. Pero a mí también un ejemplo familiar me impulsa a abordar un empeño de esta naturaleza. Mi tío materno, que fue al mismo tiempo mi padre adoptivo, escribió libros de historia y ciertamente con meticulosa veracidad» (2005: 265). 
romanos. No obstante, merece pasar a la posteridad como expositor de los descubrimientos de los demás (1992: 180).

En su descargo, y para relativizar la tensión entre la cultura libresca y la experiencial, ¿es fácil observar al camaleón? En líneas generales, desde una perspectiva actual, podemos afirmar que «el comportamiento tranquilo del camaleón común, las características morfológicas (espectacular uso de la lengua, movimiento ocular), etológicas (display cromático, vida arborícola), y alimentarias (facilidad de mantenimiento), han atraído tradicionalmente a numerosos aficionados, habiendo sido frecuente observar a niños (y algunos mayores) con camaleones como mascotas», y haciendo Historia, que «no es una afición nueva» y «Séneca apunta la tendencia de los patricios por mantener camaleones en sus jardines» (Blasco, Pérez Bote y Cabo, 2000: 22-23). No obstante, hemos de tener en cuenta lo que ya manifestaba el propio Belon: resulta complicada, para empezar, su detección, porque pasan desapercibidos gracias a su color, muy parecido al de los árboles entre los que habitan (1554: 98) ${ }^{5}$. Además, como apunta Mariño Ferro, «resulta difícil captar cuándo caza los insectos» debido a la extremada rapidez con que ejecuta el movimiento de la lengua (1996: 81), y seguro que el lector recuerda fotografías de ese preciso momento en algún libro, e imágenes de documentales en ralentí, dado que a velocidad normal no se percibe bien su peculiar técnica.

Así pues, y de nuevo en descargo de Plinio, no es solo a partir de la observación directa del animal vivo, por más dosis de paciencia que se imprima al estudio, sino mediante disección ${ }^{6}$, según apuntaba Belon y veremos con algunos testimonios más, como se podía marcar un cambio de rumbo en la percepción sobre esta propiedad del animal.

Llegados a este punto, cabe preguntarse lo siguiente: una vez resuelto, ¿de dónde procede la persistencia en el error y la continuidad del tópico? Por una parte, se debe a simple testarudez. Si hoy día, en la era de Internet y la hipercomunicación tecnológica (aunque no sé si a pesar de ello o por causa de ello), hay quienes creen que incluso el propio ser humano puede vivir sin alimentarse, y se ha denominado «respiracionismo»al disparate (Mulet, 2014: 31-33), no es de extrañar la resistencia a abandonar la misma creencia aplicada a un pequeño reptil del que apenas se sabía nada, por más que las

\footnotetext{
${ }^{5}$ Sucede así que, como apunta Cándido Santiago Álvarez a propósito de los refranes sobre animales invertebrados no artrópodos, «la baja representación paremiológica se debe al modo de vida poco aparente de estos animales, si exceptuamos el caracol, que no facilita ni la observación ni el encuentro» (2011: 32). De ahí que sobre el camaleón solo he logrado registrar los dos más conocidos en torno al cambio de color y el sustento del aire (con variantes), además de uno muy pintoresco, de filiación andaluza, Más ojos que un camaleón viejo (Fernán Caballero, 1876: 436), y el misógino El hombre que sea león y la mujer camaleón (Fernández Poncela, 2002: 54).

${ }^{6}$ Véase al respecto lo que explica Farrington, a propósito de una larga etapa de retroceso tras los logros de la época alejandrina, en la investigación en anatomía humana y animal: «los grandes avances en biología realizados por Aristóteles y en anatomía y fisiología humana por Herófilo, Erasístrato y Galeno, se hicieron a costa de trabajo personal áspero y desagradable, disecando animales vivos y muertos»; se produjo, en cambio, como denunciaría Vesalio, un «abandono de la práctica personal de la disección, debido al desprecio del hombre nacido libre hacia el trabajo manual» (1992: 190-191), que ya con la mentalidad renacentista comenzaría a cambiar porque el conocimiento anatómico incluso se aplicó, como es bien sabido, a las artes. El giro en España está bien documentado a partir del influjo de Vesalio (Alberti López, 1948: 7-8), y el comentarista de una nueva traducción del siglo XVII de la Historia natural, Francisco Hernández, explica que tuvo oportunidad de ver un camaleón y «después de muerto le anatomizamos yo y algunos médicos», aunque no encontraron restos de alimento, sino «una sarta de huevos que tenía, tan larga que estoy maravillado cómo pudo caber en animal tan pequeño» (Plinio, 1999: 399).
} 
pruebas de lo contrario sean evidentes. Así, por ejemplo, el conservadurismo de un militar como Luis de Mármol para aceptar novedades que trunquen el «estado de las cosas» en que cree vivir, es notable:

Algunos quieren decir que el camaleón, cuando se pone al sol, saca un papo donde se vienen a poner las moscas, y que de ellas se mantiene. No aprobamos tal parescer, aunque vimos muchos en Berbería, especialmente en el Reino de Marruecos, sino que del aire y de los rayos del sol se mantiene (1573: 30) ${ }^{7}$.

Por otra parte, hay razones que no guardan relación con el hermetismo ideológico y la resistencia a admitir las novedades, sino que son de tipo literario y se orientan al ornatus y/o la moralización, según comprobaremos con varios ejemplos en los dos siguientes apartados, ya que la «verdad» (averiguada o no) es asunto secundario cuando la paremia y el símil resultan efectivos.

Así, por más que sean frecuentes las acusaciones hacia el «vulgo» de propagar la idea errada (como veremos a continuación respecto a la paremia), será también (y sobre todo) la vía culta la que consolide el topos. De hecho, los estudiosos no se ponen de acuerdo sobre quién es el receptor al que se dirige Plinio, su principal difusor, con su Historia natural. Por ejemplo, René Martin y Jacques Gaillard destacan que el autor latino escribe «pour le peuple, pour les paysans et les artisans, pour ceux en un mot qui n'ont pas fait d'études; il y a chez lui une réelle volonté de démocratiser le savoir et un souci profond de se rendre utile aux humbles et aux pauvres» (1995: 181); en cambio, Michael von Albrecht opina que «l'opera di Plinio non è uno scritto didattico; oggi lo si assegnerebbe al genere enciclopedico, che si rivolge al lettore colto» (1994: 1266). Quizá podríamos consensuar, con Joan Gómez Pallarès, que,

a pesar de su vasta erudición, el carácter de la obra pliniana no es selectivo en cuanto a lectores se refiere. Plinio no se dirige en concreto a los especialistas, sino que intenta construir una enciclopedia útil a la mayor parte de público posible. Su objetivo último es la difusión de una cultura general, en este caso, relacionada con las ciencias de la naturaleza, y entre un público diríamos ni muy instruido ni muy iletrado (2003: 142).

En todo caso, como la discusión sobre su receptor ideal puede tornarse bizantina, lo que sí resulta indudable es que «su influjo, que obviamente siempre despertó el interés de los filólogos, también se extiende al ensayo, a la literatura de creación, a la historia, al arte e incluso al refranero popular» (Moure Casas, 2008: 204).

Son además los diccionarios (a menudo muy conservadores a la hora de incorporar cambios, aunque dos de los que vamos a citar son muy sui géneris y de autoría individual) un precioso ejemplo de que los indicios sobre el modo de alimentarse del camaleón tardaron en germinar. Covarrubias introduce ya una alusión experiencial, pero no discute la idea: «Este animalejo vi en Valencia en el huerto del señor patriarca don Juan de Ribera,

\footnotetext{
${ }^{7}$ El cambio de color, propiedad que aquí he soslayado para centrarme en la del sustento del aire, también ha generado confusiones y errores contumaces, como el de que imita el color de aquello a lo que se acerca (salvo el rojo y el blanco, como destacaban los moralistas y consignaban los repertorios de comparaciones como el de Pérez de Moya, 1584: 94v), cuando en realidad la función del camuflaje ya la sostiene su propio cromatismo natural y son otras las razones (el estado de ánimo, la preparación para el cortejo o la demostración de fuerza) que motivan sus más llamativos cambios. De hecho, hasta los recientes estudios del genetista evolutivo de la Universidad de Ginebra Michel Milinkovitch no parece haber quedado claro que el camaleón no muda su apariencia exactamente para ocultarse y mimetizando el entorno (Jones, 2018: s. p.).
} 
de la mesma figura que le pintan. Es cosa muy recebida de su particular naturaleza mantenerse del aire» (1987: 274, s.v. camaleón). Más de una centuria después se atisba en el Diccionario de autoridades, que fusila todavía, por cierto, a Plinio en varias partes de su descripción del animal, una cierta reorientación del asunto, ya que se admite al menos una doble posibilidad: «Algunos creyeron se mantenía solo del aire, pero otros afirman se sustenta de los mosquitos que coge» (RAE, 1976: 300, s.v. chamaleon). Pero será en ese mismo que hemos llamado Siglo de las luces cuando Terreros ilumine el asunto aportando un definitivo estado de la cuestión en su diccionario. Tras rebatir nada menos que a Aristóteles (y aludiendo a disecciones), al que se había seguido hasta entonces para negar que el reptil tuviera «carne y sangre», ofrece un contundente testimonio con pruebas de diverso signo y varios hitos experienciales:

Asimismo se engañaron los antiguos que dijeron se mantenía del aire, pues, lo primero, se le han hallado varias moscas en el cuerpo; y, lo segundo, habiendo ido yo mismo a ver uno que habían trahído de Orán a la calle de Alcalá en esta Corte, le puse por curiosidad cerca de una mosca y sacó allí en mi presencia su lengua, y enredada la mosca en su jugo glutinoso, la tragó a vista de todos los de la casa en que estaba, que afirmaron no haberle visto comer hasta entonces [...]. En la calle de Atocha vi este año de 1765 otro [...]. Hoi tengo un camaleón en mi pequeño gabinete [...] (1987: 321-322, s.v. camaleón).

El procedimiento, merced a la insaciable curiosidad que se le ha atribuido a Terreros (Carriscondo Esquivel, 2008: 15-16), es impecable: parte de un error difundido por vía libresca (de ahí que aluda a Aristóteles y a Plinio en su artículo, que es muy extenso), lo refuta con la prueba de la disección, que reafirma mediante experimentación (y sorprendiendo a quienes aún no lo habían visto comer), y la observación continúa a lo largo del tiempo, llegando a tener uno muy cerca en el momento de la redacción.

Resulta significativo, además, que explique la prueba de la mosca como si de un ilusionista ante un público atónito se tratara. Si se me permite tomármelo, por un momento, a chanza, ¿acompañó a Terreros la suerte de que el animal tuviera hambre en ese momento, o la mosca era demasiado suculenta? Si nadie lo vio en acción hasta entonces, tal vez es porque a ninguno de los presentes se le ocurrió realizar el experimento al dar por sabido que se alimentaba del aire, hasta que Terreros, que ya daba crédito, naturalmente, a las noticias de disecciones, probó. Parecerá una puesta en escena de ilusionista (a la ciencia, al fin y al cabo, hay que saber venderla también), pero desde entonces, como advertiremos enseguida, la percepción sobre el animal empezará a cambiar.

\section{FoRMULACIONES Y GLOSAS DE LA PAREMIA SUSTENTARSE DEL AIRE COMO EL CAMALEÓN}

En su Vocabulario de 1627, Correas glosa la paremia, que ofrece bajo la forma Sustentarse del aire como el camaleón, tomando tres sutiles precauciones: «no se le ve comer, y tiene siempre la boquilla abierta como para tragar aire, y ansí dicen que se sustenta del aire» (2000: 759). El paremiólogo obra con cautela al indicar, en primer lugar, no que no se alimente, sino que «no se le ve»; en segundo lugar, emplea una partícula comparativa (como) para vincular de forma oblicua y no literal la noción de tener la boca abierta con la de tragar aire (lo cual representa un modo de refutarla); por último, recuerda que son otros los que «ansí dizen», de manera que vuelve a distanciarse del tópico. La triple operación de despersonalización contrasta notablemente con la contundencia con que aludían hasta entonces los diccionarios a la idea. 
La cualidad del cambio de color será la que más aflore en las colecciones de paremias, pero volvemos a encontrar una valiosa referencia a nuestro lugar común en Caro y Cejudo: «Vivir del aire como camaleón: Dezimos esto de los que se sustentan de vanidad y aplausos vanos» (1675: 405). El desplazamiento de la idea de nutrición (literal) a la de vanidad (traslaticia) se produce porque el referente es ahora Erasmo y sus Adagiorum Chiliades Quatuor (1508) ${ }^{8}$. Téngase en cuenta que la colección de Caro y Cejudo traza lazos entre la faceta popular (representada por el refrán) y la culta (en torno al adagio), como se venía haciendo desde la anterior centuria. Así lo explica Pilar Vega Rodríguez:

En el siglo XVI se consolida un proceso de dignificación proverbial que aporta al refrán antiguo la veneración renacentista por los productos populares. Una orientación netamente erasmista propicia en este momento el cotejo de las unidades repertoriadas en los Adagia con los proverbios castellanos (1993: 234).

Lo que se ha producido en el caso del camaleón es una contaminación de nociones por vía de la moralización ${ }^{9}$. Las dos ideas (alimentación del aire y cambio de color) han confluido porque ofrecen algo en común: la visión circunspecta en torno a la vanidad y asociada, en última instancia, a la lisonja, imágenes vinculadas al reptil tan recurrentes en la emblemática. Aquí tenemos ya la reorientación del Plutarco que explicaba «Cómo distinguir a un adulador de un amigo» en sus Moralia (1992: 212-213), y, en su estela, del Erasmo de los Adagios y el Chamaeleonte imitari (III, CCLXXXI) como representación del parásito social (1574: III, 362) ${ }^{10}$. Por fin se ha encontrado en el pequeño animal una manera de que las dos propiedades tradicionalmente admitidas discurran en la misma dirección: la denuncia del afán cortesano ${ }^{11}$.

\footnotetext{
${ }^{8}$ Ha pasado más desapercibido, pero Erasmo también apunta a la extraña peculiaridad vivificándola mediante diálogo en su espléndido convite religioso: «Tim[oteo]: ¿Qué manera de lagarto tan estraña es ésta? / Eus[ebio]: No es lagarto, sino camaleón. / Tim[oteo]: ¿Éste es aquel tan famoso camaleón, de quien tantos autores hablan? Por mi fe, que yo pensava que era tanto mayor que el león en el cuerpo como en el nombre. / Eus[ebio]: Éste es aquel que siempre parece bever los ayres, siempre hambriento e ayuno» (2005: 99). Tengamos en cuenta que la recreación conversacional permite trazar un puente (aquí patente en los deícticos) entre la representación iconográfica del animal (y lo que de él hablan «tantos autores») y el que tienen delante los interlocutores, que «parece» (lo cual relaja la identificación) «beber los ayres», y que no es que no se alimente nunca en sentido estricto, sino que está «hambriento e ayuno». Se trata, por tanto, de un buen ejemplo «representado al vivo» de lo que sugería Belon en su tratado.

${ }^{9}$ Por otra parte, ya Aristóteles había vinculado en cierto modo las dos propiedades: «El cambio de color se le produce cuando se hincha de aire» (1992: 105), y la emblemática recogió con insistencia la asociación de ideas.

${ }^{10}$ Téngase en consideración también, entre los Adagios de Erasmo, el Chamaeleonte mutabilior (III, IV, I) en cuanto a sus características biológicas (1574: 560), que, como apunta Oltra, será «el que asiente el tópico desde su enorme prestigio» (1994: 878); y, para el caso que aquí nos ocupa, el Vento vivere (IV, IX, III), donde cita al animal achacando al «vulgo» la creencia (1574: 806).

${ }^{11}$ Más difícil resulta hablar de contaminación con la expresión beber los vientos o beber los aires, por más que el parecido sea evidente, pero vale la pena lanzar la sugestión: aunque el origen de la expresión parece estar asociado a los perros de caza, ya Correas consignaba la forma beber los vientos y los elementos, y además de la orientación amorosa, se activaba la idea «del que anda en pretensión que mucho desea» (Iribarren, 1993: 24). Nótese que en la obra que aquí nos servía de punto de partida hay un llamativo «muchas veces se les pasa la vida bebiendo los vientos como camaleones y cebándose en esperanzas vanas» (Torquemada, 2011: 98) a propósito de los criados y sus relaciones con los señores. En el origen del dicho, la noción asociada al perro es activa (de hecho, se refiere al afán con que olfatea), mientras que la del camaleón es pasiva, pero aquí probablemente se ha producido un caso de sincretismo por asociación entre beber y sustentarse.
} 
Este fenómeno sincrético aflorará en varios textos literarios y de ello daré cuenta en el siguiente apartado, pero conviene atender ya a que también hay una tendencia popular (y no solo culta) que vincula la propiedad con lo amoroso. Así, en la relación de «Comparaciones populares recogidas en Osuna» por Rodríguez Marín para la revista $E l$ Folk-Lore andaluz fundada por Demófilo, aparece Se mantiene del aire, como los camaleones, y se ejemplifica con esta copla:

Mi camaraíta y yo semos dos fuertes leones; nos mantenemos del aire como los camaleones (1882: 369).

Al desdén amoroso apunta asimismo esta otra copla flamenca del siglo XIX:

Soy como el camaleón, que se mantiene del aire; ¡y tú eres león sangriento, que se mantiene con carne! (Balmaseda, 2001: 60).

Volviendo a la línea «recta» del sustento del aire, que discurrirá en paralelo con la otra en la mayoría de colecciones, e instalados ya de pleno en lo que Combet denominó «le renouveau des études parémiologiques au XIXe siècle» con Sbarbi (1971: 326-329), este ofrece dos glosas de la paremia que merece la pena recordar: en la summa que ya vio la luz póstumamente bajo el título de Gran diccionario de refranes de la lengua española, el paremiólogo gaditano apostillaba, bajo la forma Mantenerse del aire, como el camaleón, lo siguiente: «Frase que debe su origen a la preocupación en que está el vulgo de que el camaleón se mantiene de aire, creencia tan ridícula como absurda» (1943: 47). No sería justo entrar en disquisiciones apresuradas sobre el empleo que el autor realiza del término «vulgo», aquí netamente despectivo, mientras que en su encendida defensa de la paremia (1980b: V-VIII y 1-60) resulta mejor parado. Lo que sí conviene advertir para nuestro recorrido son los matices que muestra en esta otra explicación de Sustentarse del aire como el camaleón, con relevantes cambios de significado:

Dícese de la persona a quien para el mantenimiento de la vida le basta con alimentarse escasa y tardíamente. También se dice de aquél a quien presta poco la comida, que parece que se sustenta del aire, etc., con alusión a la costumbre que tiene dicho animal de alargar la lengua fuera de la boca por un gran espacio de tiempo, a fin de que la cubran las hormigas y podérselas comer de una vez (1980a: 56).

Frente a la simple indignación de su primera glosa, Sbarbi ya da noticia de uno de los modos como cree que se alimenta el camaleón y termina desplazando el significado: ya no designa al que no come nada, sino al que come poco (primera acepción) y al que lo hace de una manera muy determinada (segunda acepción). Ha cambiado la percepción que se tiene del animal y eso ha modificado, en consecuencia, la propia sustancia de la paremia. Esto, como veremos al término del siguiente apartado, sucederá de manera semejante en el empleo literario de la expresión.

\section{INCIDENCIA EN LA LITERATURA DEL LUGAR COMÚN}

Como ejemplo de la fortaleza de los vasos comunicantes, de nuevo, entre lo culto y lo popular, merece la pena mudar aquí, como punto de arranque, una cita extensa: 
Correas aprovechará al máximo la fuente literaria, especialmente la de la poesía popular, para realizar su obra, pero ésta será el gran pozo sin fondo del que beban la mayor parte de los literatos que deseen incorporar el acerbo común de sabiduría popular a sus obras. El corpus documental paremiológico de los siglos XVI y XVII era ya abundante y prácticamente estaba fijado. De él se aprovecharán los literatos, contribuyendo, al mismo tiempo, con su literatura a aumentarlo, ennoblecerlo o simplemente a ponerlo en circulación, transformándolos a veces, en contextos literarios nuevos y en situaciones sociales e históricas cambiantes (González Martín, 1997: 283).

Una muestra de esta incidencia en la literatura a propósito de las propiedades del camaleón ya nos la brindaron en dos excelentes trabajos José Miguel Oltra (1994) para la picaresca y Lía Schwartz (2005) para Quevedo. Si ampliamos la perspectiva cronológica, y de nuevo centrándonos en el sustento del aire, apreciamos la doble vía del rechazo (sobre todo en textos dialogales) y de la aceptación (podríamos decir que «interesada» debido a razones estilísticas).

No sorprende que en dos espléndidos coloquios del siglo XVI como los Diálogos familiares de la agricultura cristiana de Pineda y los Coloquios de Palatino y Pinciano de Arce de Otálora, auténticos libros troquelados por cuanto tasan al vivo estados de la cuestión candentes en su época, se ponga en entredicho el tópico. En la plática sobre la expulsión del aire, a propósito de la voz, que mantienen los conversantes de Pineda, se refuta de forma contundente (y alegando razones que ya repasamos anteriormente) lo que afirmaba el principal difusor del topos:

Filótimo: [...] Plinio tiene que no se halla dentro del camaleón otro miembro, si no es el pulmón, porque siente en esto que se mantiene del aire, mas sin duda es falsa su filosofía, pues es cuerpo de gruesa substancia, y ansí ha menester nutrimento grueso, y se ha visto el camaleón comer las moscas que se le llegan a la boca (1963: 256-257).

De acuerdo con su dinámica acumulativa y tras varias digresiones donde cita al animal, más adelante introduce hábilmente el símil asociado al cambio de color para deslindar la propiedad testada y la que es considerada falsa:

Filótimo: Pues yo quiero que me satisfaga el señor Pánfilo las injurias que me dijo, con descubrirnos el misterio o el secreto, que yo no alcanzo, en aquellos tres animales a que me comparó, a lo menos del pulpo y del tarando.

Policronio: Yo le ruego lo mesmo.

Pánfilo: Aquellos tres animales andan muy notados de que se tornan del color que tienen las cosas a que se allegan; y aun hay quien presuma defender que el camaleón se sustente con comer aire, como mienten otros que el pez halec con agua sola, y el topo con sola tierra, y la salamandra en el fuego (1964: 314).

Y la petición de los interlocutores le permite examinar ya en particular al camaleón poniendo en boca de Pánfilo (de nombre parlante sin duda, pero que «con la poca filosofía que he deprendido» se defiende bastante bien) un extenso discurso donde delimita con pulcritud las claves del asunto, de forma semejante a la explicación de Belon:

Y metiendo mano en la materia del camaleón, animalejo más traído en plática, digamos con Aristóteles y con Plinio y Solino, que con ser del tamaño de la lagartija, el tornarse de tan varios colores cuales los tienen las cosas a que se allega, le proviene de 
ser medrosísimo, y este miedo procede de no tener sangre, sino muy poca en el corazón y en los ojos; y por la falta de la sangre dice Aristóteles ser medrosos los hombres de la tierra caliente y animosos los de la tierra fría, donde los hombres tienen mucha sangre por la providencia de naturaleza contra la ponzoña del frío [...]. Lo del no comer más de viento es de Plinio y de Solino, mas repugna a la verdad filosófica, que no consiente que cuerpo compuesto de los cuatro elementos se mantenga con uno solo, sino con substancia compuesta de todos cuatro, y las experiencias nos enseñan que come moscas y otras cosillas semejantes, sino que como por la falta de sangre sea frigidísimo, gasta poco, y bástale poco, y permanece muchos días sin comer, y por ventura le ayuda el aire a se sustentar su parte, y por esto debe de estar siempre la boca abierta; y nota Aristóteles que se hincha para mudar sus colores (1964: 314-315).

Con su habitual donaire, los platicantes de Arce de Otálora discuten sobre la posibilidad de que algunos hombres hayan vivido largo tiempo (o incluso toda la vida) sin comer, y Palatino lo pone en duda bromeando con lo que se decía de nuestro reptil: «Ese tal debía de ser de casta de camaleones o de linaje de las cigarras que cuenta Platón, que, por beneficio de las musas, se sustentan sin comer ni beber. Todos esos son cuentos de viejas» (Arce de Otálora,1995: I, 290). Ahora bien, igual que Torquemada en el citado pasaje de su Jardín de flores curiosas, se termina insistiendo en que hay autoridades que refrendan esas historias de vidas sin sustento alimenticio, de modo que hemos de acudir a otro intercambio pleno de gracejo para confirmar cómo los interlocutores se toman a chanza el tópico:

Palatino: No me ternía por engañado si me librasen el almuerzo en ese manjar, que más hambre tienen los ojos y el corazón que el estómago, y en mejor plato se emplearían.

Pinciano: Por amor de vos quiero acabar con estas señoras que salgan aquí y os dejen gozar de su vista, pues os queréis mantener della como el camaleón del aire; y entretanto, yo almorzaré lo que hallare (1995: II, 607-608).

Los amigos se van de requiebros y quieren comer a costa de unas damas, de forma que se trata de una broma a partir del juego dilógico entre sustento amoroso y sustento nutricio, como se aprecia en dos textos también dialogales, aunque de muy distinto tenor (y orientación erótica mezclada sutilmente con alusión a lo monetario en sendas referencias), La Lozana andaluza y la Segunda Celestina:

Lozana: Señor, ya podéis pensar: mujer que es estada cuatro sábados mala y sin ayuda de nadie, ¡mirá si tengo de darme priesa a rehacer el tiempo perdido! ¿Qué pensáis, que me tengo de mantener del viento como camaleón? No tengo quien se duela de mí, que vosotros sois palabras de presente y no más (Delicado, 2004: 197).

Elicia: Ay, tía, como si te encubriesse yo cosa. Veamos, de las doblas que Crito me dio, ¿hete demandado blanca?

Celestina: Mas pidiéssesla; pardiós, hija, que no eres camaleón para pedir lo que no das, que te sostienes de solo aire, digo, como te conviene si has de gozar del paxe roxo; y a cabo de mil años que te doy vestido, y calçado y de comer me çahieres dos negras doblas empezinadas. ¡Guayas de las doblas y de la nada!, que para vino son menester cada mes diez. Busca, busca hija, quien te dé ropa y quien te calce, y déxate de gentilezas, que no hemos, en fin, de comer dellas (Silva, 1988: 563-564). 
En estos dos últimos textos no hay cuestionamiento alguno del tópico porque el símil resulta muy efectivo para designar la inacción asociada al camaleón ${ }^{12}$. Así se apunta, por ejemplo, a la pobreza en un romance atribuido a Góngora: «qu'es condición de poetas / parezer camaleones» (1998: 327), que podría haber suscrito Cervantes cuando se le ocurrió aquello de la «poetambre»; o para lamentar la ausencia amorosa, como propone Lope en Servir a señor discreto:

Pedro: Hoy, con alguna invención,

le contaré mi partida

y pues he sido en la vida

del viento camaleón

cisne en la muerte seré

porque perderla es mejor

que no que mi mucho amor

piense que fingido fue (1975: 170-171).

Con Quevedo, cómo no, topamos con acusados contrastes al leer un precioso soneto donde incorpora el tópico (hábilmente relacionado con el de la salamandra y el fuego) en el clímax de los tercetos para la expresión amorosa:

Fui salamandra en sustentarme ciego

en las llamas del sol con mi cuidado,

y de mi amor en el ardiente fuego;

pero en camaleón fui transformado

por la que tiraniza mi sosiego,

pues fui con aire della sustentado (1969: 530).

Y en cambio se mofa de la idea en este otro, que ha venido a llamarse explícitamente «Búrlase del camaleón, moralizando satíricamente su naturaleza»:

Dígote pretendiente y cortesano,

llámete Plinio el nombre que quisiere;

pues quien del viento alimentarte viere,

el nombre que te doy tendrá por llano.

$[\ldots]$

Si del aire vivieras, almorzaras

respuestas de ministros y señores;

consultas y decretos resollaras (1970, 35-36).

Se trata de una reorientación moralizante, con contaminación de las dos propiedades $^{13}$, como ya apreciamos a propósito de los vaivenes paremiológicos, pues

${ }^{12}$ El carácter pasivo del animal llamó la atención de Plutarco, quien discutiendo «Sobre la inteligencia de los animales» lo contraponía por ese aspecto al pulpo (2002: 315-316), y Ripa incluso lo asoció, destacando su pusilanimidad, a la adulación porque esta es «indicio de poco valor y ánimo bajo en quien la ejercita, y aún en quien la escucha gustoso» (1987: 67). Observamos así que unas supuestas propiedades fisiológicas (que derivan en rasgos de carácter) son transferidas a términos morales con suma facilidad. Algo parecido sucedió con la inanición, que podía trasladarse fácilmente a desdenes amorosos.

13 José Miguel Oltra aprecia bien (y lo funda con un despliegue erudito tan oportuno como encomiable), a propósito del soneto, que «Francisco de Quevedo sintetizará la propuesta asumiendo las dos características principales» (1994: 882), pero en el objeto al que conduce su estudio, la picaresca, no advierte la confluencia de las dos propiedades (1994: 886). Es difícil establecer la línea divisoria, no 
finalmente se refiere a los «aduladores» (y no olvidemos la célebre formulación «hidrópica de viento» de las Soledades de Góngora). Como bien explica Lía Schwartz, «la analogía se había cristalizado, de este modo, en los discursos populares y en la paremiología culta, así como en la emblemática, convirtiéndose en fuente de conceptos para Quevedo» (2005: 165), y en el citado soneto satírico,

redescripción de la naturaleza del camaleón en la que creyó descubrirse un comportamiento humano, Quevedo recoge, por un lado, toda la información «científica», transmitida desde Aristóteles y Plinio por diccionarios, colecciones de sentencias, proverbios y emblemas, centrada aquí en la creencia popular de que vivía del aire. Por el otro, enlaza una serie de tipos privilegiados en su universo satírico porque viven del aire, metafóricamente, o porque expiran el aire del que se alimentaría el camaleón (2005: 167168).

Creo que las más altas cotas del tópico al servicio del asunto amoroso, de nuevo con mixtura de los componentes del cambio de color y la referencia al aire, se encuentran en la Jornada II del drama mitológico de Calderón Eco y Narciso:

Eco: [...] Amor sabe con cuánta

vergüenza llego a hablarte,

y no dudo ni temo

que tú también lo sabes,

si atiendes los colores

que en el rostro me salen,

la púrpura y la nieve

variada por instantes;

porque en cada suspiro,

que en efecto son aire,

camaleón de amor

se muda mi semblante (2000: 618) ${ }^{14}$.

Estos versos introducen un sutil juego estilístico que cimbrea el motivo del color mudable (que ya no excluye el blanco y el rojo, según insistían los moralistas, sino que los pone en primer término) asociado al pudor, recoge en su trayecto el lugar común del aire como único sustento del enamorado, y una vez abonada hábilmente la senda metafórica, remata con la imagen del «camaleón de amor» que termina siendo el rostro de Eco ${ }^{15}$.

Avanzando en el tiempo, si aún encontramos, por ejemplo, la línea moralizante en la censura de Carlos de la Reguera al Correo del otro mundo de Torres Villarroel cuando se refiere a «los que, camaleones de novedades, se sustentan del aire de los que fingen»

obstante, en el siguiente ejemplo del Guzmán de Alfarache, que tal vez sí responda al sincretismo en torno al concepto de la vanidad: «Que el poderoso se hinche, tiene de qué y con qué; mas que el necesitado se desvanezca, es camaleón, cuanto traga es aire sin sustancia. Y así, aunque es aborrecible el rico vano, tanto es insufrible y escandaloso el pobre soberbio» (Alemán, 1999: 342).

${ }^{14}$ Agradezco al profesor David Mañero Lozano la referencia al drama de Calderón, cuya mención al reptil puso amablemente a mi disposición. Asimismo debo a su erudición el conocimiento de una posible pervivencia del tópico (con significativa mención del aire pero no ya del camaleón) en una canción registrada en el Corpus de Literatura Oral de la Universidad de Jaén: https://www.corpusdeliteraturaoral.es/Archivo-Sonoro/cancionero/yo-me-enamoré-del-aire.

${ }^{15}$ Es notable el servicio retórico del topos, como en aquel retruécano, atribuido a Góngora y recogido por Agustín Durán, de «por lo bravo se llama / al dormir león sin cama, / y al comer camaleón» (1829: 127), y que García-Page consigna asignándolo a Quevedo en su repaso por el recurso estilístico (19911992: 178). 
(1725: s. p.), o en Isla y su Fray Gerundio al aludir a los «camaleones que se sustentan del ayre de los ergos y que tienen las navetas tan vacías de chocolate como los cascos llenos de questiones impertinentes» (1758: 206), la recurrencia a la paremia disminuye considerablemente durante el siglo XIX, frente al vigor que sigue manifestando la propiedad más célebre del cambio de color ${ }^{16}$. La línea cronológica discurre así paralela a lo que ya observamos en la paremiología con el hiato de Sbarbi.

Si nos valemos del Corpus de Referencia del Español Actual (CREA) de la RAE para rastrear la huella literaria del tópico, apreciamos que ya no hay apenas alusiones a la alimentación del aire porque la referencia al cambio de color la ha desplazado ${ }^{17}$. Eso sí, podemos comprobar que la alusión a su sustento sigue considerándose efectiva en las obras de ficción, aunque desde un significativo viraje: «con la celeridad y tino de un camaleón, que dispara su lengua para atrapar una libélula, arrojó su garrote como si se tratase de un arpón ballenero» (Fernando Savater, Caronte aguarda, 1981); «sacando una lengua muy larga, con ligereza y habilidad de camaleón, para agarrar al vuelo la moneda que don Lisardo echó por el aire» (Germán Sánchez Espeso, En las alas de las mariposas, 1985).

Se ha impuesto así la percepción de cómo se alimenta el camaleón (y en sentido netamente positivo, destacándose su destreza) frente a la idea, tantas veces asociadas al ser humano de forma cáustica, de que no se alimenta en modo alguno. Esto da la razón, de paso, a las intuiciones del alumnado a propósito del texto con el que partíamos, y justifica su desconcierto porque se ha debilitado (cuando no perdido) esa extraña impresión sobre el animal.

\section{CODA: CONFORMACIÓN DE UNA PREVERDAD}

Lo que se ha producido en el arco que hemos examinado es una pervivencia de la paremia porque, en primer lugar, se daba por cierta la propiedad que la sustanciaba, a continuación se vacilaba en darle crédito y en todo caso se acogió (sintetizándose con el tópico más célebre del cambio de color) porque su desplazamiento metafórico permitía útiles giros estilísticos para el discurso literario; finalmente, perdió su vigor cuando el lugar común más reconocible, en lugar de abrazarla y avivarla, la oscureció (de ahí su difícil reconocimiento por parte del hablante actual).

Si contemplamos su trayectoria, tenemos otro ejemplo de que las vías popular y culta discurren imbricadas, porque no es solo «el vulgo» al que aludía Sbarbi el que mantuvo viva la llama del símil sobre el camaleón, sino los literatos que la reformularon y la incorporaron a sus textos en variados registros amorosos y morales, llegando incluso a fundirse las dos percepciones tradicionales sobre el animal.

En definitiva, hemos comprobado que, como advierte Ana Fernández Poncela, los refranes no son verdades, sino «una ventana desde la cual mirar la vida y el mundo»

16 Todavía Galdós recupera el sentido literal del sustento del aire, como en Doña Perfecta: «Las pobrecitas son honradas. ¡Bah! Si se alimentan del aire, como los camaleones. Diga usted: el que no come, ¿puede pecar? Bastante virtuosas son las infelices. Y si pecaran, limpiarían su conciencia con el gran ayuno que hacen» (2004a: 439-440); o en Misericordia: «De modo que estás como los camaleones. No te apures, que Dios aprieta, pero no ahoga, y aquí estoy yo para que no ayunes más de la cuenta» (2004b: 318).

${ }^{17}$ Con el auxilio del Corpus del Español del Siglo XXI (CORPES XXI) de la RAE, que incluye tanto textos escritos como orales, podemos refrendar la evolución: de los 353 casos que he obtenido bajo el lema camaleón, 42 aluden explícitamente al cambio de color (y cuando transfieren, mediante símil, la cualidad al ser humano, lo hacen tanto en atribución positiva como negativa), y las 3 únicas que aparecen sobre la alimentación, inciden en su peculiar lengua, de manera que el sustento del aire, como era previsible, se ha volatilizado. 
(2012: 20). A propósito de estas ventanas, el inquietante término posverdad se ha aplicado sobre todo al ámbito político, pero es extensible a una nueva forma de ver el mundo y de relacionarnos con él en términos más generales, en especial dentro de lo que se ha llamado modernidad líquida. Atendamos por un momento a quien mejor ha explicado el proceso, Zygmunt Bauman:

el aprendizaje y la educación fueron creados a la medida de un mundo que era duradero, esperaba continuar siendo duradero y apuntaba a hacerse aún más duradero de lo que había sido hasta entonces. En semejante mundo, la memoria era un valor positivo, tanto más rico cuanto más lejos en el pasado lograra llegar y cuanto más tiempo se conservara. Hoy, una memoria tan sólidamente atrincherada parece, en muchos casos, potencialmente inhabilitante, en muchos más engañosa y, en la mayoría, inútil. [...] En nuestro volátil mundo de cambio instantáneo y errático, las costumbres establecidas, los marcos cognitivos sólidos y las preferencias por los valores estables, aquellos objetivos últimos de la educación ortodoxa, se convierten en desventajas (2008: 36-37).

A la luz de lo que hemos observado a propósito del camaleón, precioso ejemplo para reivindicar, con Nuccio Ordine (2013), «la utilidad de lo inútil» y nuestras maltrechas Humanidades, podríamos preguntarnos lo siguiente desde la sugestión de estos tiempos líquidos: ¿no hay también una preverdad? Se trata de algo que en primera instancia se da por sabido y que aflora, gracias al rescate paremiológico y a la recurrencia literaria, incluso mucho después de quedar demostrado el error. Y no me refiero a la «falibilidad de los adagios» que denunciaba Feijoo en otra línea, la del relativismo moral $^{18}$, sino al fragmento de memoria atávica que representa, independientemente de su validez científica, el símil, dicho o proverbio. La paremiología podría dar cuenta, sin duda, de muchas de estas fascinantes preverdades.

18 «Cualquiera que pronuncia que todo el Mundo afirma tal, o tal cosa, ¿tomó por ventura uno por uno, ni aun en montón, el parecer de todos los hombres?» (Feijoo, 1997: 1-2). 


\section{BIBLIOGRAFÍA}

ALBERTI LÓPEZ, Luis (1948): La anatomía y los anatomistas españoles del Renacimiento, Madrid, CSIC.

Albrecht, Michael von (1994): Storia della letteratura latina. De Livio Andronico a Boezio, II, Turín, Einaudi.

Alciato, Andrea (2003): Los emblemas de Alciato. Traducidos en rimas españolas. Lion, 1549, ed. Rafael Zafra, Barcelona, José J. de Olañeta / UIB.

AlemÁn, Mateo (1999): Guzmán de Alfarache, ed. Francisco Rico, Barcelona, Planeta.

ÁlvareZ-Ossorio, Antonio (2000): «Proteo en Palacio. El arte de la disimulación y la simulación del cortesano», en El Madrid de Velázquez y Calderón. Villa y corte en el siglo XVII. I. Estudios históricos, Miguel Morán y Bernardo J. García (eds.), Madrid, Fundación Caja Madrid/Ayuntamiento, pp. 111-137.

ARANDA, Juan de (1613): Lugares comunes de conceptos, dichos y sentencias en diversas materias (1595), Madrid, Juan de la Cuesta.

ArCe de OtÁlorA, Juan de (1995): Coloquios de Palatino y Pinciano, ed. José Luis Ocasar Ariza, Madrid, Turner.

ARISTÓTELES (1992): Investigación sobre los animales, ed. Julio Pallí Bonet, Madrid, Gredos.

BAlmaseda, Manuel (2001): Primer cancionero de coplas flamencas populares según el estilo de Andalucía (1881), ed. Enrique Baltanás, Sevilla, Signatura Ediciones.

BAUMAN, Zygmunt (2008): Los retos de la educación en la modernidad líquida, Barcelona, Gedisa.

BERGER, John (2008), Mirar, Barcelona, Gustavo Gili.

Blasco RuIZ, Manuel, José Luis Pérez Bote y José Manuel CABo HernándeZ (2000): «Algunas reflexiones sobre el declive del camaleón común (Chamaeleo chamaeleon, L. 1758) en la Península Ibérica», Mediterránea. Serie de estudios biológicos, 17, pp. 5-51. DOI: https://doi.org/10.14198/MDTRRA2000.17.04

CABALlero, Fernán (1878): Cuentos, oraciones, adivinas y refranes populares $e$ infantiles, Madrid, T. Fortanet.

CALDERÓn DE LA BARCA, Pedro (2000): Eco y Narciso, ed. Ángel Valbuena Briones, en Obras maestras, coord. José Alcalá-Zamora y José María Díez Borque, Madrid, Castalia.

CARO Y CEJUDO, Jerónimo Martín (1675): Refranes y modos de hablar castellanos con latinos, Madrid, Julián Izquierdo.

CARriscondo ESQUivel, Francisco M. (2008): «La labor lexicográfica de Esteban de Terreros», Oihenart, 23, pp. 13-34.

CHEVALIER, Jean y Alain GHEERBRANT (1986): Diccionario de los símbolos, Barcelona, Herder.

CORREAS, Gonzalo (2000): Vocabulario de refranes y frases proverbiales (1627), ed. L. Combet, Madrid, Castalia.

COMBET, Louis (1971): Recherches sur le «refranero» castilian, París, Les Belles Lettres. COVARRUBIAS, Sebastián de (1987): Tesoro de la lengua castellana o española (1611), ed. Martín de Riquer, Barcelona, Alta Fulla. 
DeliCADO, Francisco (2004): La Lozana andaluza, ed. Carla Perugini, Sevilla, Fundación José Manuel Lara.

DURÁn, Agustín, ed. (1829): Cancionero y romancero de coplas y canciones de arte menor, Madrid, Eusebio Aguado.

ERASMO DE RotTERDAM, Desiderio (1574): Adagiorum Chiliades Quatuor (1508), Basilea, Eusebium Episcopium y Nicolai Fr. Haeredes.

ERASMO DE RotTerdam, Desiderio (2005): Coloquios familiares. Edición de Alonso Ruiz de Virués (siglo XVI), ed. Andrea Herrán y Modesto Santos, Barcelona, Anthropos.

FARRINGTON, Benjamin (1992): Ciencia y filosofía en la Antigüedad, Barcelona, Ariel.

FEIJOO, Benito Jerónimo (1997): «Falibilidad de los Adagios» (1750), en Cartas eruditas y curiosas, ed. digital Biblioteca Feijoniana. URL: $<$ http://www.filosofia.org/bjf/bjfc301.htm>.

FERNÁNDEZ PONCELA, Ana María (2002): Estereotipos y roles de género en el refranero popular, Barcelona, Anthropos.

FERNÁNDEZ PONCELA, Ana María (2012): «La cultura popular: los refranes hoy», Revista de Folklore, 364, pp. 17-32.

GARCÍA GARCÍA, Alicia María (2007): Juba II, rey de Mauritania: traducción y comentario de sus fragmentos (Tesis Doctoral), Universidad de La Laguna.

GARCÍA-PAGE, Mario (1991-92): «El retruécano léxico y sus límites», Archivum, 41-42, pp. 173-203.

Gómez PallaréS, Joan (2003): Stvdiosa Roma. Los géneros literarios en la cultura romana. Notas para su explicación, de Apio Claudio a Isidoro, Bellaterra, Universidad de Barcelona.

GóngORA, Luis de (1998): Romances, IV, ed. Antonio Carreira, Barcelona, Quaderns Crema.

GONZÁLEZ MARTíN, Vicente (1997): «El refrán en la literatura española de los siglos XVI y XVII», Paremia, 6, pp. 281-286.

Huerta, Jerónimo de (1602): Tradución de los libros de Caio Plinio Segundo de la Historia natural de los animales, Alcalá, Justo Sánchez Crespo.

IRIBARREN, José María (1993): El porqué de los dichos, Pamplona, Gobierno de Navarra.

ISLA, José Francisco de (1758): Historia del famoso predicador fray Gerundio de Campazas, alias Zotes, I, Madrid, Gabriel Ramírez.

JONES, Benji (2018): «Los cambios de color más llamativos de los camaleones no son para camuflarse», Nationalgeographic.es. URL: $<$ https://www.nationalgeographic.es/animales/2018/08/los-cambios-de-colormas-llamativos-de-los-camaleones-no-son-para-camuflarse>.

MALAXECHEVERRÍA, Ignacio, ed. (1986): Bestiario medieval, Madrid, Siruela.

MAL LARA, Juan de (1996): Obras completas, I. Philosophía vulgar, ed. Manuel Bernal Rodríguez, Madrid, Turner.

MARIÑO FERRO, Xosé Ramón (1996): El simbolismo animal. Creencias y significados en la cultura occidental, Madrid, Encuentro.

MÁRMOL, Luis del (1573): Primera parte de la Descripción general de África, Granada, René Rabut.

MARTIN, René y Jacques GAILlARD (1995): Les genres littéraires à Rome, París, Nathan / SCODEL.

MARTÍNEZ KLEISER, Luis (1993): Refranero general ideológico español, Madrid, Hernando. 
Moure CASAS, Ana (2008): «Plinio en España: panorama general», Revista de Estudios Latinos, 8, pp. 203-237.

Mulet, José Miguel (2014): Comer sin miedo: mitos, falacias y mentiras sobre la alimentación en el siglo XXI, Barcelona, Destino.

OlTRA, José Miguel (1994): «A propósito del camaleón: la transmisión de un topos erudito», en Hommage à Robert Jammes, III, Francisco Cerdan (ed.), Toulouse, Presses Universitaires du Mirail, pp. 875-888.

ORDINE, Nuccio (2013): La utilidad de lo inútil, Barcelona, Acantilado.

OviDIO, Publio (1990): Metamorfosis, III, ed. Antonio Ruiz de Elvira y Bartolomé Segura Ramos, Madrid, CSIC.

PÉREZ DE MOYA, Juan (1584): Comparaciones o símiles para los vicios y virtudes, Alcalá de Henares, Juan Gracián.

PÉRez Galdós, Benito (2004a): Doña Perfecta, en Obras Completas. II, ed. Federico Carlos Sainz de Robles, Madrid, Aguilar.

PÉrez Galdós, Benito (2004b): Misericordia, en Obras Completas. V, ed. Federico Carlos Sainz de Robles, Madrid, Aguilar.

PineDA, Juan de (1963): Diálogos familiares de la Agricultura cristiana, II, ed. Juan Meseguer, Madrid, Atlas.

PinEDA, Juan de (1964): Diálogos familiares de la Agricultura cristiana, IV, ed. Juan Meseguer, Madrid, Atlas.

Plinio Cecilio Segundo (el Joven), Cayo (2005): Cartas, edic. Julia González Fernández, Madrid, Gredos.

Plinio Segundo (El VieJo), Cayo (1999): Historia Natural (1624), trad. Francisco Hernández y Jerónimo de Huerta, Madrid, Visor / UNAM.

PlUTARCO (1992): «Cómo distinguir a un adulador de un amigo», en Obras morales y de costumbres (Moralia). I, ed. Concepción Morales Otal y José García López, Madrid, Gredos.

Plutarco (2002): «Sobre la inteligencia de los animales», en Obras morales y de costumbres (Moralia). IX, ed. Vicente Ramón Palerm y Jorge Bergua Cavero, Madrid, Gredos.

Quevedo, Francisco de (1969): Obra poética, I, ed. José Manuel Blecua, Madrid, Castalia.

QueVedo, Francisco de (1970): Obra poética, II, ed. José Manuel Blecua, Madrid, Castalia.

RAE (1970): Diccionario de autoridades (1726), I, ed. facsímil, Madrid, Gredos.

RIPA, Cesare (1997): Iconología (1593), I, Madrid, Akal.

RODRÍGUEZ MARÍN, Francisco (1882): «Comparaciones populares recogidas en Osuna», El Folk-Lore andaluz, 9, pp. 361-370.

SÁnCHEZ DE VIANA, Pedro (1589): Las transformaciones de Ovidio, Valladolid, Diego Fernández de Córdoba.

SANTIAGO ÁlvaREZ, Cándido (2011): «Refranes sobre animales invertebrados no artrópodos», Revista de Folklore, 355, pp. 32-41.

SBARBI, José María (1943): Gran diccionario de refranes de la lengua española (1922), ed. Manuel J. García, Buenos Aires, Joaquín Gil.

SBARBI, José María (1980a): Ramillete o florilegio alfabético de refranes y modismos (1873), Madrid, Atlas.

SBARBI, José María (1980b): El refranero general español, I (1874), Madrid, Atlas. 
SEVILla MuÑOZ, Julia (1996): «Sobre la paremiología española», Euskera, 41, 3, pp. 641-672.

SCHWARTZ, Lía (2005): «De camaleones y pretendientes en la poesía de Quevedo», en De Fray Luis a Quevedo. Lecturas de los clásicos antiguos, Málaga, Universidad, pp. 155-169.

SiLva, Feliciano de (1988): Segunda Celestina, ed. Consolación Baranda, Madrid, Cátedra.

Solino (2001): Colección de hechos memorables o El erudito, ed. Francisco J. Fernández Nieto, Madrid, Gredos.

TERREROS Y PANDO, Esteban (1987): Diccionario castellano con las voces de ciencias y artes (1786), I, ed. facsímil, Madrid, Arco Libros.

TORQUEMADA, Antonio de (1982): Jardín de flores curiosas, ed. Giovanni Allegra, Madrid, Castalia.

TORQUEMADA, Antonio de (2011): Coloquios satíricos, ed. Rafael Malpartida, Málaga, Anejos de Analecta Malacitana.

TORRES Villarroel, Diego de (1725), Correo del otro mundo, Salamanca, Eugenio García de Honorato y S. Miguel.

VegA, Lope de (1975): Servir a señor discreto, ed. Frida Weber de Kurlat, Madrid, Castalia.

Vega RodrígueZ, Pilar (1993), «El refranero de Luis Galindo y los Adagia de Erasmo», EPOS, 9, pp. 233-253. DOI: https://doi.org/10.5944/epos.9.1993.9836

Fecha de recepción: 28 de mayo de 2019

Fecha de aceptación: 29 de mayo de 2019

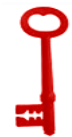

